\title{
Effects of dietary supplementation of arginine and lysine on performance and egg quality characteristics of laying quails
}

\author{
Tuba BÜLBÜL ${ }^{1}$, Elmas ULUTAŞ ${ }^{2}$, Mustafa EVCIMMEN² \\ University of Afyonkocatepe, Faculty of Veterinary Medicine, ${ }^{1}$ Department of Animal Nutrition and Nutritional Disease, \\ ${ }^{2}$ Department of Physiology, Afyonkarahisar. Turkey.
}

\begin{abstract}
Summary: The aim of the present research was to determine the effects of arginine and lysine supplementation in laying quail diets on performance and egg quality characteristics. A total of 420 Japanese quails (280 females and 140 males; Coturnix coturnix japonica) aged 10 weeks old were divided into seven equal groups, each consisting of 60 quails. The control group was fed a basal diet without the addition of arginine or lysine (with an arginine:lysine ratio at the required level). Experimental groups were fed the basal diet supplemented with: $0.1 \%$ arginine; $0.2 \%$ arginine; $0.1 \%$ lysine; $0.2 \%$ lysine; $0.1 \%$ arginine $+0.1 \%$ lysine; or $0.2 \%$ arginine $+0.2 \%$ lysine. Feed intake decreased in the $0.1 \%$ lysine, $0.2 \%$ lysine, and $0.1 \%$ arginine $+0.1 \%$ lysine groups compared with the control and arginine groups $(\mathrm{P}<0.01)$. At the end of the experiment, body weight increased for females in all experimental groups $(\mathrm{P}<0.05)$; eggshell thickness decreased in the $0.2 \%$ arginine group $(\mathrm{P}<0.01)$; and the albumen index increased in the $0.2 \%$ arginine $+0.2 \%$ lysine group compared with the $0.1 \%$ arginine, $0.2 \%$ lysine, and $0.1 \%$ arginine $+0.1 \%$ lysine groups $(\mathrm{P}<0.05)$. There were no differences between the experimental groups in terms of egg production, egg weight, feed conversion ratio, shape index, Haugh unit, yolk index, albumen index and yolk color index. In conclusion, lysine supplementation in the quail diets did not appear to have any significant negative effect; excessive arginine supplementation might impair the quality of the eggshell; and combined arginine and lysine supplementation did not improve performance.
\end{abstract}

Key words: Arginine, egg quality characteristics, laying quails, lysine, performance.

\section{Yumurtacı bıldırcın rasyonlarına arjinin ve lizin ilavesinin performans ve yumurta kalite özellikleri üzerine etkisi}

Özet: $\mathrm{Bu}$ araştırma yumurtacı bıldırcın rasyonlarına arjinin ve lizin ilavesinin performans ve bazı yumurta kalite özellikleri üzerine etkisini belirlemek amacıyla yapıldı. Araştırmada toplam 420 adet (280 dişi ve 140 erkek) 10 haftalık Japon bıldırcını her biri 60 bıldırcından oluşan 7 gruba ayrıldı. Kontrol grubu arjinin ve lizin ilavesi yapılmayan (arjinin:lizin oranı gereksinim düzeyinde olan) temel rasyonla beslenirken, deneme grupları temel rasyona $\% 0.1$ arjinin, $\% 0.2$ arjinin, $\% 0.1$ lizin, $\% 0.2$ lizin, $\% 0.1$ arjinin + $\% 0.1$ lizin ve $\% 0.2$ arjinin $+\% 0.2$ lizin katılarak oluşturuldu. Yem tüketiminin $\% 0.1$ lizin, $\% 0.2$ lizin ve $\% 0.1$ arjinin $+\% 0.1$ lizin gruplarında kontrol ve arjinin gruplarına göre düştüğü belirlendi $(\mathrm{P}<0.01)$. Deneme sonunda canlı ağırlığın dişilerde tüm deneme gruplarında arttığı $(\mathrm{P}<0.05)$, yumurta kabuk kalınlığının \% 0.2 arjininli grupta azaldığ $1(\mathrm{P}<0.01)$, albumin indeksi ise \% 0.2 arjinin $+\% 0.2$ lizin grubunda $\% 0.1$ arjinin, $\% 0.2$ lizin ve $\% 0.1$ arjinin $+\% 0.1$ lizin gruplarına göre arttı $\breve{g}_{1}(\mathrm{P}<0.05)$ tespit edildi. Yumurta verimi, yumurta ağırlı̆̆ı, yemden yararlanma oranı, şekil indeks, Haugh birimi, sarı indeks, ak indeks ve sarı renk indeksi yönünden ise deneme gruplarında değişiklik oluşmadığı belirlendi. Sonuç olarak bıldırcın rasyonlarına lizin ilavesinin belirgin olumsuz etkisi bulunmadığı, gereğinden fazla arjinin ilavesinin yumurta kabuğu kalitesini bozabileceği, arjinin ve lizinin birlikte ilavesinin ise performans üzerine etkili olmadığ 1 ifade edilebilir.

Anahtar sözcükler: Arjinin, lizin, performans, yumurta kalite özellikleri, yumurtacı bıldırcın.

\section{Introduction}

In poultry diets based on corn-soybean meal, lysine is specified as the second limiting amino acid, followed by arginine (25). Arginine and lysine are important for poultry nutrition in terms of the promotion and development of growth $(8,11,12,19)$, egg production and egg quality $(15,26,27,28)$. Body-weight (BW) gain, feed intake (FI) and feed conversion ratio (FCR) in poultry are adversely affected by deficiencies of these amino acids $(6,14,20,21)$. In contrast, excessive levels of these amino acids in the diet have been found to result in impaired growth performance $(4,7,8,9,10)$, and to not have any positive effects on egg production and quality (2).

It has been reported that the optimum arginine: lysine ratio in a diet enhances the requirement for arginine in association with increasing the lysine level (34). Increasing arginine:lysine ratios have no impact on 
livability performance (35), egg production, or weight and quality (31) in the case of adequate levels of both amino acids in the diet. However, Kidd and Kerr (18) determined that an increased arginine:lysine ratio in the diet positively affects BW gain and FCR. Therefore, the objective of this study was to determine the effects of arginine, with or without lysine supplementation, at different levels in Japanese quail diets on performance and egg quality characteristics.

\section{Materials and Methods}

Animals: A total of 420 (280 females and 140 males) 10-week-old Japanese quails (Coturnix coturnix japonica) were used in this study. The research procedure was approved by the Ethics Committee of Afyon Kocatepe University (AKÜHADYEK-214-13). There were seven groups, each containing 60 laying quails, in the experiment. Each group was divided into four replicate groups consisting of 15 quails each. Quails were placed in individual pens for 8 weeks and were given feed and water ad libitum under conditions of 16 hours light -8 hours dark.

Diets and experimental treatments: The feed raw materials were obtained from a commercial company (Tinaztepe Feed Factory, Afyonkarahisar). The basal diet (20.00\% crude protein, 1.24:0.99 arginine:lysine ratio, and $2900 \mathrm{kcal} / \mathrm{kg}$ metabolizable energy) was formulated to meet the nutrient requirements of quails recommended by the National Research Council (NRC) (25).

The control group was fed a basal diet without the addition of arginine or lysine (Table 1). The experimental groups were fed the basal diets with supplementation of $0.1 \%$ arginine (L-arginine, Sigma A5131 powder form); $0.2 \%$ arginine; $0.1 \%$ lysine (L-lysine- $\mathrm{HCl}$ ); $0.2 \%$ lysine; $0.1 \%$ arginine $+0.1 \%$ lysine; or $0.2 \%$ arginine $+0.2 \%$ lysine, respectively. The nutrient composition of the basal diet, including moisture, crude protein, crude fat, crude fibre, crude ash and calcium contents, was determined according to the AOAC (1). The metabolizable energy level of the basal diet was calculated according to Carpenter and Clegg (23). The arginine and lysine levels of the basal diet were determined by liquid chromatography-tandem mass spectrometry (LC-MS/MS) (Applied Biosystems API3200; ANT Technical Devices Laboratory) (Table 1).

Performance parameters: BW was determined at the beginning and end of the study. FI was identified biweekly as the group average. FCR was calculated on the same days as the amount of feed consumed per $\mathrm{kg}$ egg. Daily egg production records were kept in groups. The eggs' weights were measured biweekly.

Egg quality parameters: In this study, 12 eggs from each group (three eggs from each replicate) were collected to determine the internal and external quality parameters of the eggs once every 4 weeks. The eggs were
Table 1. Ingredients and chemical composition of basal diet, $\%$. Tablo 1 . Temel rasyonun yem ham maddeleri ve besin madde bileşimi, \%.

\begin{tabular}{|c|c|}
\hline Ingredients & $\%$ \\
\hline Corn & 50.02 \\
\hline Wheat & 3.96 \\
\hline Full fat soybean & 12.07 \\
\hline Soybean meal & 14.04 \\
\hline Sunflower meal & 3.59 \\
\hline Corn gluten meal & 6.66 \\
\hline Vegetable oil & 2.00 \\
\hline Limestone & 5.05 \\
\hline Salt & 0.33 \\
\hline Dicalcium phosphate & 1.55 \\
\hline $\mathrm{NaHCO}_{3}$ & 0.23 \\
\hline L-Lysine & 0.10 \\
\hline DL-Methionine & 0.05 \\
\hline Vitamin mineral premix $^{1}$ & 0.35 \\
\hline \multicolumn{2}{|l|}{ Chemical composition (analysed) } \\
\hline Dry matter, $\%$ & 91.35 \\
\hline Crude ash, $\%$ & 9.42 \\
\hline Crude protein, $\%$ & 20.60 \\
\hline Ether extract, \% & 6.04 \\
\hline Crude fiber, $\%$ & 3.52 \\
\hline Nitrogen free extract, $\%$ & 51.77 \\
\hline Calcium, \% & 2.50 \\
\hline Available phosphorus, $\%$ & 0.35 \\
\hline Metabolisable energy $^{2}, \mathrm{kcal} \mathrm{kg}^{-1}$ & 2914 \\
\hline Arginine $^{3}, \%$ & 1.24 \\
\hline Lysine $^{3}, \%$ & 0.99 \\
\hline Methionine $^{4}, \%$ & 0.45 \\
\hline Methionine+cystine ${ }^{4}, \%$ & 0.81 \\
\hline
\end{tabular}

${ }^{1}$ Each $\mathrm{kg}$ of diet: Retinol acetate, $4.1 \mathrm{mg}$; cholecalciferol, $0.075 \mathrm{mg}$; DL- $\alpha$-tocopherylacetate, $11 \mathrm{mg}$; menadione, $1 \mathrm{mg}$; thiamin, $2.8 \mathrm{mg}$; riboflavin sodium phosphate, $5.8 \mathrm{mg}$; niacin, $44 \mathrm{mg}$, pyridoxine, $4 \mathrm{mg}$; cyanocobalamin, $0.026 \mathrm{mg}$; Ca-D-pantothenate, $8.8 \mathrm{mg}$; folic acid, $1 \mathrm{mg}$; choline, 220; biotin, $0.11 \mathrm{mg}$; Cu, $6 \mathrm{mg}$; I, $1.1 \mathrm{mg}$; Fe, $30 \mathrm{mg}$; Se, $0.1 \mathrm{mg}$; $\mathrm{Mn}, 60 \mathrm{mg}$; Zn, $50 \mathrm{mg}$

2 Metabolisable energy (ME) content of diets was estimated using the equation devised by Carpenter and Clegg (Leeson and Summers, 2001): $\operatorname{ME}(\mathrm{kcal} / \mathrm{kg})=53+38[($ crude protein $\%)+(2.25 \mathrm{x}$ ether extract $\%)+(1.1 \times \operatorname{starch} \%)+($ sugar $\%)]$.

3 The arginine and lysine levels of the basal diet were determined by LC-MS-MS (Applied Biosystems API-3200, ANT Technical Devices Lab.)

4 The methionine and methionine+cystine levels of the basal diet were calculated according to the Batal and Dale (3) 
examined for weight $(\mathrm{g})$, length $(\mathrm{mm})$, width $(\mathrm{mm})$, eggshell thickness $(\mathrm{mm})$, fracture strength, albumen index $(\%)$, yolk index $(\%)$, Haugh unit, egg shape index and yolk color index. Egg width, egg length, yolk width, albumen length and albumen width were measured by compass to the nearest $0.01 \mathrm{~mm}$. Albumen and yolk heights were measured by micrometer to the nearest 0.01 $\mathrm{mm}$. Egg shape, yolk and albumen indexes were calculated from these measures (5). The Haugh unit was calculated with the formula developed by Haugh (16). Measurements of the thickness of dried shells with the membrane were obtained from two sides in the equatorial region, as well as on the blunt and pointed edges with a micrometer to the nearest $0.01 \mathrm{~mm}$ (5). The egg yolk visual color score was determined by matching the yolk with one of the 15 bands of the 1961 'Roche improved yolk color fan'. The formulas used in the measurement of egg quality parameters were as follows:

Shape index $(\%)=[$ egg width $(\mathrm{mm}) /$ egg length $(\mathrm{mm})] \mathrm{x}$ 100

Yolk index $(\%)=[$ yolk height $(\mathrm{mm}) /$ yolk width $(\mathrm{mm})] \mathrm{x}$ 100

Albumen index $(\%)=$ albumen height $(\mathrm{mm}) /[$ (average albumen length $(\mathrm{mm})+$ width $(\mathrm{mm}) / 2) \times 100]$

Haugh unit $=100 \log$ [albumen height $(\mathrm{mm})+7.57-1.7$ $\mathrm{x}$ egg weight $\left.{ }^{0.37}(\mathrm{~g})\right]$

Statistical analysis: The variance analysis method was used for all statistical calculations and the significance of differences between the mean values of the groups according to the data obtained from the research. Duncan's test was applied to control the significant difference between groups (SPSS 10.00; SPSS Inc., Chicago, IL, USA). A value of $\mathrm{P}<0.05$ was considered as the limit for statistical significance (13).

\section{Results}

Performance: Initial BW did not change depending on sex in the groups in which arginine and lysine were given singly or combined $(P>0.05)$. Compared with the final $\mathrm{BW}$ of female and male quails, arginine and lysine supplementation did not cause a change in the BW of males, whereas the BW of females increased $(\mathrm{P}<0.05)$ in all experimental groups compared with the control group. FI did not change over the course of the experiment $(P>0.05)$, whereas it was determined during the entire research that FI reduced $(\mathrm{P}<0.01)$ in the $0.1 \%$ lysine, $0.2 \%$ lysine, and $0.1 \%$ arginine $+0.1 \%$ lysine groups compared with the control and arginine groups. The values of egg production, egg weight and FCR were not affected by arginine and lysine levels in the diets in the experiment (Table 2).

Egg quality: Eggshell thickness and the albumen index showed no changes in any of the experimental groups compared with the control group in the 4 th week.
In the 8th week, eggshell thickness decreased $(\mathrm{P}<0.01)$ in the $0.2 \%$ arginine group compared with the control and other experimental groups. Albumen index increased $(\mathrm{P}<0.05)$ in the $0.2 \%$ arginine $+0.2 \%$ lysine group compared with the $0.1 \%$ arginine, $0.2 \%$ lysine, and $0.1 \%$ arginine $+0.1 \%$ lysine groups. At the 4 th and 8 th weeks of the experiment no changes in the other egg quality parameters were determined in terms of the shape index, yolk index, Haugh unit and yolk color index (Table 3).

\section{Discussion and Conclusions}

In the present study, the control group diet was formulated to have optimal arginine and lysine levels and arginine:lysine ratio according to NRC (25) recommendations; the ratio of arginine:lysine was found to be 1.24:0.99. Final BW increased in female quails $(\mathrm{P}<0.05$; Table 2). Several studies conducted with broilers $(6,19,21,34)$ reported that arginine and lysine supplementation affected BW gain positively, while it was decreased by arginine and lysine deficiency (14, 20, 22). On the other hand, excessive arginine and lysine supplementation in the diet (twice the level of requirement) has been reported to lower BW gain for chicks (7) or keep it steady for chickens (2) and chicks $(4,32)$. Other studies reported that arginine and lysine supplementation had positive effects only under stressful circumstances (33); the requirement changed depending on the protein level of the diet $(17,24)$. In the present study, the BW of female quails increased due to arginine and lysine supplementation; the species and sex of the poultry could be a factor when considering the supplementation of amino acids in diets. In addition, the diets suggested for chickens might not always be valid for quails.

During the experiment, total FI decreased $(\mathrm{P}<0.01)$ in the lysine-only-supplemented groups and the $0.1 \%$ arginine $+0.1 \%$ lysine group (Table 2 ). In laying hens, supplementation with arginine and lysine in combination at the same levels (2) and an increase of lysine only in the diet have been reported to be probable causes of FI reduction (30). Also, it has been reported that high lysine levels in the diets of broilers might reduce FI $(7,24)$. Some studies $(6,20)$ suggest that arginine and lysine deficiency in diets might have a suppressive effect on FI. Nevertheless, Basiouni et al. (2) reported that increasing levels of lysine, more than arginine, in laying hens increased FI when compared with other groups where arginine and lysine were increased together. Contrary to our results, it has also been recorded that $0.15 \%$ lysine supplementation in the diet (28), increased lysine levels in the diets $(15,26)$, and an enrichment of a diet with lysine (36) does not affect FI. Moreover, it has been reported that different arginine:lysine ratios $(1.16,1.21$, $1.26,1.31$ and 1.36) (31), by changing the arginine and lysine levels in laying quail diets, and the 
Table 2. The effects of arginine and lysine levels on performance of quail

Tablo 2. Arjinin ve lizin düzeylerinin bıldırcınlarda performans üzerine etkisi.

\begin{tabular}{|c|c|c|c|c|c|c|c|c|c|}
\hline & Control & $\begin{array}{c}0.1 \% \\
\text { Arginine }\end{array}$ & $\begin{array}{c}0.2 \% \\
\text { Arginine }\end{array}$ & $\begin{array}{c}0.1 \% \\
\text { Lysine }\end{array}$ & $\begin{array}{l}0.2 \% \\
\text { Lysine }\end{array}$ & $\begin{array}{c}0.1 \% \text { Arginine } \\
+ \\
0.1 \% \text { Lysine }\end{array}$ & $\begin{array}{c}0.2 \% \text { Arginine } \\
+ \\
0.2 \% \text { Lysine }\end{array}$ & SEM & $\mathrm{P}$ \\
\hline \multicolumn{10}{|c|}{ Initial body weight, $\mathrm{g}$} \\
\hline Female & 196.76 & 197.54 & 196.28 & 198.22 & 201.20 & 198.54 & 197.78 & 1.45 & 0.987 \\
\hline Male & 181.12 & 180.16 & 183.45 & 177.64 & 177.80 & 181.50 & 178.24 & 1.79 & 0.943 \\
\hline \multicolumn{10}{|c|}{ Final body weight, $g$} \\
\hline Female & $205.14 b$ & $223.76 a$ & $216.67 \mathrm{a}$ & $220.06 a$ & $226.13 a$ & $223.61 \mathrm{a}$ & $219.10 \mathrm{a}$ & 1.60 & 0.016 \\
\hline Male & 195.40 & 201.42 & 205.90 & 198.30 & 198.40 & 209.11 & 207.12 & 1.41 & 0.073 \\
\hline \multicolumn{10}{|c|}{ Egg production, $\%$} \\
\hline 2nd week & 80.00 & 74.20 & 82.20 & 73.80 & 74.60 & 73.20 & 71.50 & 1.41 & 0.397 \\
\hline 4th week & 80.71 & 80.35 & 81.25 & 86.25 & 81.07 & 83.21 & 77.67 & 1.24 & 0.728 \\
\hline 6th week & 77.22 & 81.38 & 76.11 & 83.05 & 85.83 & 83.33 & 79.16 & 1.41 & 0.534 \\
\hline 8th week & 78.28 & 79.37 & 73.59 & 81.09 & 80.31 & 79.37 & 81.71 & 1.15 & 0.622 \\
\hline $0-8$ weeks & 79.00 & 78.83 & 78.83 & 81.04 & 80.45 & 79.78 & 77.83 & 0.68 & 0.907 \\
\hline \multicolumn{10}{|l|}{ Egg weight, g } \\
\hline 2nd week & 12.04 & 12.20 & 12.07 & 11.88 & 12.34 & 12.53 & 12.60 & 0.09 & 0.301 \\
\hline 4th week & 12.76 & 13.14 & 13.00 & 13.25 & 13.40 & 13.49 & 12.69 & 0.09 & 0.156 \\
\hline 6th week & 12.91 & 12.97 & 12.22 & 12.69 & 12.91 & 13.16 & 12.43 & 0.10 & 0.157 \\
\hline 8th week & 13.59 & 13.73 & 13.17 & 13.29 & 13.56 & 13.67 & 13.14 & 0.11 & 0.721 \\
\hline $0-8$ weeks & 12.92 & 13.01 & 12.61 & 12.72 & 13.05 & 13.21 & 0.06 & 0.09 & 0.234 \\
\hline \multicolumn{10}{|c|}{ Feed intake, g/day } \\
\hline 2nd week & 26.92 & 25.90 & 26.11 & 25.70 & 25.29 & 25.09 & 24.88 & 0.28 & 0.563 \\
\hline 4th week & 26.72 & 27.54 & 27.13 & 25.50 & 26.11 & 26.92 & 28.35 & 0.27 & 0.104 \\
\hline 6th week & 27.94 & 28.15 & 28.56 & 26.92 & 26.31 & 26.11 & 26.52 & 0.28 & 0.111 \\
\hline 8th week & 28.76 & 29.17 & 29.58 & 27.13 & 26.52 & 27.74 & 27.94 & 0.29 & 0.049 \\
\hline $0-8$ weeks & $27.59 \mathrm{a}$ & $27.69 \mathrm{a}$ & $27.84 \mathrm{a}$ & $26.31 b$ & $26.06 \mathrm{~b}$ & $26.46 \mathrm{~b}$ & $26.92 \mathrm{ab}$ & 0.16 & 0.001 \\
\hline \multicolumn{10}{|c|}{ Feed conversion ratio, $\mathrm{kg}$ feed $/ \mathrm{kg}$ egg } \\
\hline 2nd week & 3.02 & 3.36 & 2.93 & 3.49 & 3.18 & 3.28 & 3.73 & 0.10 & 0.470 \\
\hline 4th week & 2.60 & 2.61 & 2.60 & 2.28 & 2.41 & 2.41 & 2.91 & 0.05 & 0.122 \\
\hline 6th week & 2.75 & 2.68 & 3.08 & 2.57 & 2.38 & 2.38 & 2.75 & 0.06 & 0.038 \\
\hline 8th week & 2.74 & 2.76 & 3.06 & 2.48 & 2.45 & 2.57 & 2.60 & 0.06 & 0.191 \\
\hline $0-8$ weeks & 2.72 & 2.81 & 2.90 & 2.72 & 2.56 & 2.59 & 2.92 & 0.04 & 0.238 \\
\hline
\end{tabular}

Letters $(a, b)$ in the same line indicate significant differences between different letters.

supplementation of $0.25 \%$ lysine (29) do not change FI. The decrease in FI in the groups in which only lysine was supplemented in the present study might have stemmed from inadequate arginine levels in the diet, as Kwak et al. (21) reported. The FI decrease in groups with low levels of arginine and lysine supplementation might be linked to the birds lowering the FI in order to protect the arginine:lysine ratio, even though arginine and lysine increased together.

In the present study, arginine and/or lysine supplementation in diets resulted in no differences between the groups in terms of egg production, egg weight and FCR during the separate weeks or the entire study (Table 2). It has been reported that supplementation of arginine and lysine in the diet does not affect egg production, egg weight or FCR in laying quails (31) and hens (2). In contrast, it has also been reported that $0.25 \%$ lysine supplementation in quail diets reduced egg weight (29) and $0.15 \%$ lysine supplementation increased egg production and egg weight in hens (28). The present research shows that arginine and lysine do not affect egg production, egg weight and FCR of quails at the applied levels.

In this study, no changes were recorded in the 4th and the 8th weeks for egg quality parameters such as shape index, yolk index, Haugh unit and yolk color. In the 4th week no changes between the groups were determined for albumen index (Table 3). Basiouni et al. (2) also reported that arginine:lysine ratios from the contribution of arginine and lysine at different levels into the diet do not affect albumen height, which is an internal egg quality characteristic. In contrast, the arginineforming arginine silicate-inositol complex was claimed to increase the Haugh unit (27). Eggshell thickness was 
negatively affected by the high level of arginine supplied in the 8th week $(\mathrm{P}<0.01$, Table 3$)$. Contrary to our findings, Onderci et al. (27) reported that due to the relationship between silicon and calcium (which is vital for determining shell thickness), and arginine's disruption of the absorption of calcium, dietary arginine silicate-inositol complex supplementation at $0.05 \%$ and $0.1 \%$ levels led to an increase in shell thickness. Conversely, Önol et al. (28) found that $0.15 \%$ lysine supplementation in hens did not change the shell thickness. The decrease in the thickness of the shell in this study might have resulted from the arginine:lysine ratio being much higher in the group in which arginine was used at an excessive level compared with the other groups. In the 8th week of the research the albumen index increased $(\mathrm{P}<0.05)$ in the $0.2 \%$ arginine $+0.2 \%$ lysine group compared with the low level of arginine and arginine + lysine groups, as well as the high-level lysine groups (Table 3). This increase in the albumen index could be linked to the use of arginine and lysine together at high levels and an increased level of protein. Moreover, the high level of the albumen index in the $0.2 \%$ arginine $+0.2 \%$ lysine group might have resulted from the egg weights being quantitatively higher in this group than in the others.
As a result, arginine supplementation $(0.1 \%$ and $0.2 \%)$ with or without lysine supplementation $(0.1 \%$ and $0.2 \%$ ) in the diets of quails did not affect egg production, egg weight or FCR; however, arginine supplementation at the level of $0.2 \%$ reduced eggshell thickness. Hence, arginine and/or lysine supplementation above the required levels in quail diets may not lead to a change in performance and egg quality. The arginine and lysine levels reported by the NRC may be sufficient for feeding laying quails. Moreover, it is suggested that studies are needed to clarify the relationship of the arginine:lysine ratio with different environmental conditions, electrolyte balance, or other amino acids.

\section{References}

1. AOAC (Association of Official Analytical Chemists) (2000): Official Methods of Analysis (1 $17^{\text {th }}$ ed.). AOAC International, Maryland, USA.

2. Basiouni G, Najib H, Zaki MM, Al-Ankari AS (2006): Influence of extra supplementation with arginine and lysine on overall performance, ovarian activities and humoral immune response in local Saudi hens. Int J Poult Sci, 5, 441-448.

3. Batal A, Dale N (2013). Ingredient analysis table: 2014 edition. Feedstuffs, 85:16-17.

Table 3. The effects of arginine and lysine levels on egg quality parameters of quail

Tablo 3. Arjinin ve lizin düzeylerinin bıldırcınlarda yumurta kalite parametreleri üzerine etkisi.

\begin{tabular}{|c|c|c|c|c|c|c|c|c|c|}
\hline & Control & $\begin{array}{c}0.1 \% \\
\text { Arginine }\end{array}$ & $\begin{array}{c}0.2 \% \\
\text { Arginine }\end{array}$ & $\begin{array}{c}0.1 \% \\
\text { Lysine }\end{array}$ & $\begin{array}{l}0.2 \% \\
\text { Lysine }\end{array}$ & $\begin{array}{c}0.1 \% \text { Arginine } \\
+ \\
0.1 \% \text { Lysine }\end{array}$ & $\begin{array}{c}0.2 \% \text { Arginine } \\
+ \\
0.2 \% \text { Lysine }\end{array}$ & SEM & $\mathrm{P}$ \\
\hline \multicolumn{10}{|c|}{ Egg shell thickness, $\mathrm{mm} / 100$} \\
\hline 4. hafta & 20.23 & 20.04 & 20.00 & 18.86 & 18.86 & 19.78 & 19.90 & 0.21 & 0.407 \\
\hline 8. hafta & $20.11 \mathrm{a}$ & $18.71 \mathrm{a}$ & $17.03 \mathrm{~b}$ & $19.24 \mathrm{a}$ & $18.83 \mathrm{a}$ & $19.50 \mathrm{a}$ & $20.04 \mathrm{a}$ & 0.22 & 0.002 \\
\hline \multicolumn{10}{|l|}{ Haugh unit ${ }^{1}$} \\
\hline 4. hafta & 82.79 & 79.48 & 80.06 & 82.57 & 79.72 & 78.23 & 86.08 & 1.31 & 0.736 \\
\hline 8. hafta & 79.83 & 75.60 & 78.75 & 81.25 & 76.29 & 79.58 & 85.53 & 1.38 & 0.480 \\
\hline \multicolumn{10}{|c|}{ Shape index ${ }^{2}, \%$} \\
\hline 4. hafta & 77.50 & 76.96 & 77.32 & 79.03 & 76.27 & 77.78 & 78.87 & 0.34 & 0.226 \\
\hline 8. hafta & 80.71 & 78.51 & 78.78 & 80.18 & 78.57 & 79.76 & 80.80 & 0.32 & 0.316 \\
\hline \multicolumn{10}{|c|}{ Yolk index ${ }^{3}, \%$} \\
\hline 4. hafta & 42.62 & 42.32 & 42.52 & 43.90 & 41.94 & 42.77 & 43.37 & 0.17 & 0.226 \\
\hline 8. hafta & 43.31 & 42.10 & 42.25 & 43.02 & 42.14 & 42.80 & 43.36 & 0.18 & 0.326 \\
\hline \multicolumn{10}{|c|}{ Albumen index ${ }^{4}, \%$} \\
\hline 4. hafta & 8.56 & 8.09 & 8.27 & 8.38 & 7.74 & 8.10 & 9.49 & 0.15 & 0.067 \\
\hline 8. hafta & $8.61 \mathrm{ab}$ & $7.85 \mathrm{~b}$ & $8.28 \mathrm{ab}$ & $8.39 \mathrm{ab}$ & $7.37 \mathrm{~b}$ & $8.12 \mathrm{~b}$ & $9.34 \mathrm{a}$ & 0.15 & 0.026 \\
\hline \multicolumn{10}{|c|}{ Yolk colour index } \\
\hline 4. hafta & 7.91 & 7.60 & 8.06 & 8.13 & 7.80 & 8.33 & 7.73 & 0.11 & 0.636 \\
\hline 8. hafta & 7.16 & 7.26 & 7.46 & 7.86 & 7.68 & 8.03 & 7.58 & 0.11 & 0.156 \\
\hline
\end{tabular}

${ }^{1}$ Haugh unit $=100 \log$ [albumen height $(\mathrm{mm})+7.57-1.7 \times$ egg weight $\left.{ }^{0.37}(\mathrm{~g})\right]$

${ }^{2}$ Shape index $(\%)=[$ egg width $(\mathrm{mm}) /$ egg length $(\mathrm{mm})] \times 100$

${ }^{3}$ Yolk index $(\%)=[$ yolk height $(\mathrm{mm}) /$ yolk width $(\mathrm{mm})] \times 100$

${ }^{4}$ Albumen index $(\%)=$ albumen height $(\mathrm{mm}) /[($ average albumen length $(\mathrm{mm})+$ width $(\mathrm{mm}) / 2) \times 100]$

Letters $(a, b)$ in the same line indicate significant differences between different letters. 
4. Bulbul T, Bozkurt Z, Ulutas E, Yılmaz O, Bulbul A (2013): The effect of L-arginine on growth performance, some serum biochemical parameters and duodenal motility in broilers. Kafkas Üniv Vet Fak Derg, 19, 821-827.

5. Card LE, Nesheim MC (1972): Poultry Production ( $11^{\text {th }}$ ed.). Lea and Febiger, Philadelphia, 274-337.

6. Carew LB, Evarts KG, Alster FA (1997): Growth, plasma thyroid hormone concentrations of chicks fed diets deficient in essential amino acids. Poult Sci, 76,1398-1404.

7. Carew LB, Evarts KG, Alster FA (1998): Growth, feed intake and plasma thyroid hormone levels in chicks fed dietary excesses of essential amino acids. Poult Sci, 77, 295-298.

8. Cengiz O, Kucukersan S (2010): Effects of graded contents of arginin supplementation on growth performance, haematological parameters and immune system in broilers. Rev Med Vet-Toulouse, 161, 409-417.

9. Cengiz O, Onol AG, Sevim O, Ozturk M, Sari M, Daskiran M (2008): Influence of excessive lysine and/or methionine supplementation on growth performance and carcass traits in broiler chicks. Rev Med Vet-Toulouse, 159, 230-236.

10. Chamruspollert M, Pesti GM, Bakalli RI (2002): Dietary interrelationships among arginine, methionine, and lysine in young broiler chicks. Br J Nutr, 88, 655- 660.

11. Corzo A, Moran ET, Hoehler D (2003): Arginine need of heavy broiler males: Applying the ideal protein concept. Poult Sci, 82, 402-407.

12. Cuca M, Jensen LS (1990): Arginine requirement of starting broiler chicks. Poult Sci, 69, 1377-1382.

13. Daniel, WW (1991): Bioistatistics: A faundation for a analysis in the health sciences. $\left(5^{\text {th }} e d\right.$.). John Wiley \& Sons Inc., Canada.

14. D'mello JPF, Lewis D (1970): Amino acid interactions in chick nutrition. 3. Interdependence in amino acid requirements. Br Poult Sci, 2, 367-385.

15. Gunawardana P, Roland DA, Bryant MM (2008): Performance comparison and lysine requirements of seven commercial brown egg layer strains during phase one. Int J Poult Sci, 7, 806-812.

16. Haugh R (1937): The Haugh unit for measuring egg quality. US Egg Poultry Magazine, 43, 552-555.

17. Hurwitz S, Sklan D, Talpaz H, Plavnik I (1998): The effect of dietary protein level on the lysine and arginine requirements of growing chickens. Poult Sci, 77, 689-696.

18. Kidd MT, Kerr BJ (1998): Dietary arginine and lysine ratios in large white toms. 1. lack of interaction between arginine: lysine ratios and electrolyte balance. Poult Sci, 77, 864-869.

19. Kidd MT, Peebles ED, Whitmarsh SK, Yeatman JB, Wideman RF (2001): Growth and immunity of broiler chicks as affected by dietary arginine. Poult Sci, 80, 15351542 .

20. Konashi S, Takahashi K, Akiba Y (2000): Effects of dietary essential amino acid deficiencies on immunological variables in broiler chickens. Brit J Nutr ,83, 449-456.

21. Kwak H, Austic RE, Dietert RR (1999): Influence of dietary arginine concentration on lenfoid organ growth in chickens. Poult Sci, 78, 1536-1541.

22. Labadan MC Jr, Hsu KN, Austıc RE (2001): Lysine and arginine requirements of broiler chickens at two-to threeweek intervals to eight weeks of age. Poult Sci 80, 599-
606.

23. Leeson S, Summers JD (2001): Nutrition of the chicken. University Books, Guelph, Canada.

24. Morris TR, Abebe S (1990): Effects of arginine and protein on chicks' responses to dietary lysine. Br Poult Sci, 31, 261-266.

25. NRC (1994): Nutrition Requirements of Poultry. NRC, Washington, DC.

26. Novak C, Yakout H, Scheideler S (2004): The combined effects of dietary lysine and total sulfur amino acid level on egg production parameters and egg components in Dekalb Delta laying hens. Poult Sci, 83, 977-984.

27. Onderci M, Sahin N, Sahin K, Balcı TA, Gursu MF, Juturu V, Kucuk O (2006): Dietary arginine silicate inositol complex during the late laying period of quail at different environmental temperatures. Br Poult Sci, 47, 209-215.

28. Önol AG, Daşkıran M, Cengiz Ö, Nazlıül A, Sarı M (2012): Sicaklık stresi altındaki erken yumurtlama döneminde olan tavuklartn rasyonlarına E vitamini ve lizin katklsinın performans ve yumurta kabuk özellikleri üzerine etkisi. Kafkas Üniv Vet Fak Derg, 18, 49-54.

29. Preethymol J, Peethambaran PA, Jalaludeen A, Leo J (2008): Influence of dietary supplementation of lysine and methionine on production performance in laying quails. Indian J Poult Sci, 43, 62-66.

30. Prochaska JF, Carey JB, Shafer DJ (1996): The effect of L-lysine intake on egg component yield and composition in laying hens. Poult Sci, 75, 1268-1277.

31. Reis RS, Barreto SLT, Abjaude WS, Dutra DR, Santos M, Paula E (2012): Relationship of arginine with lysine in diets for laying Japanese quails. R Bras Zootec, 41, 106-110.

32. Rezaei M, Nassiri Moghaddam H, Pour Rezaj, Ker Manshahi H (2004): The effects of dietary protein and lysine levels on broiler performance, carcass characteristics and $N$ excretion. Int J Poult Sci, 3, 148-152.

33. Srinongkote S, Smriga M, Toride Y (2004): Diet supplied with L-lysine and L-arginine during chronic stress of stock normalizes growth of broilers. Anim Sci J, 75, 339-343.

34. Ueno K, Ishibashi T (1998): Arginine requirements and optimum balance between dietary arginine and lysine in broiler chicks. Anim Sci Tech, 69, 760-767.

35. Waldroup PW, England JA, Kidd MT, Kerr BJ (1998): Dietary arginine and lysine in large white toms. 1. Increasing arginine : lysine ratios does not improve performance when lysine levels are adequate. Poult Sci, 77, 1364-1370.

36. Wu G, Bryant MM, Gunawardana P, Roland Sr DA (2007): Effect of nutrient density on performance, egg components, egg solids, egg quality, and profits in eight commercial leghorn strains during phase one. Poult Sci, 86, 69-697.

Geliş tarihi: 16.01.2014/ Kabul tarihi: 30.10.2014
Address for correspondence:
Dr. Tuba Bülbül
University of Afyonkocatepe,
Faculty of Veterinary Medicine,
Department of Animal Nutrition and Nutritional Disease,
ANS Campus, Afyonkarahisar, Turkey,
e-mail: tbulbul@aku.edu.tr 